\title{
An integral algorithm for instantaneous uncut chip thickness measuring in the milling process
}

\author{
Li, Y. ${ }^{a}$, Yang, Z.J. ${ }^{a}$, Chen, C. ${ }^{b,}{ }^{*}$, Song, Y.X. ${ }^{a}$, Zhang, J.J. ${ }^{a}$, Du, D.W. ${ }^{c}$ \\ ${ }^{a}$ College of Mechanical Science and Engineering, Jilin University, Changchun, Jilin, P.R. China \\ ${ }^{b}$ College of Engineering, China Agricultural University, Beijing, P.R. China \\ 'Institution of Oceangraphic Instrumentation, Shandong Academy of Science, Qingdao, P.R. China
}

\begin{abstract}
A B S T R A C T
Instantaneous uncut chip thickness (IUCT) calculation is an essential work for dynamic cutting force prediction accurately in milling process. This study presents an integral algorithm in polar coordinate system for measuring the thickness of transient uncut chip. The milling trajectory, cycloidal motion, is adopted in the formulation. Both milling continuity and cutter run-out are also considered in this model. The developed model offers a methodology for calculating the IUCT precisely. Furthermore, a series of simulations are carried out under different processing parameters. The results suggest that increasing both the feed per tooth and number of teeth can surge the width of IUCT slightly, but decrease with smaller cutter radius. The milling force simulations are validated by the experiment results measured in the reference and compared with classical approximate method, showing the proposed IUCT model providing good applications in instantaneous milling force predictions.
\end{abstract}

(C) 2018 CPE, University of Maribor. All rights reserved.
ARTICLE INFO

Keywords:

Milling;

Instantaneous uncut chip thick-

ness;

Dynamic cutting forces;

Integral algorithm

*Corresponding author:

chenchao2018@cau.edu.cn

(Chen, C.)

Article history:

Received 7 December 2017

Revised 29 July 2018

Accepted 24 August 2018

\section{References}

[1] Omar, O.E.E.K., El-Wardany, T., Ng, E., Elbestawi, M.A. (2007). An improved cutting force and surface topography prediction model in end milling, International Journal of Machine Tools and Manufacture, Vol. 47, No. 7-8, 12631275, doi: 10.1016/i.ijmachtools.2006.08.021.

[2] Matsubara, A., Ibaraki, S. (2009). Monitoring and control of cutting forces in machining processes: A review, Monitoring and Control of Cutting Forces in Machining Processes, Vol. 3, No. 4, 445-456, doi: 10.20965/ijat.2009. p0445.

[3] Mwinuka, T.E., Mgwatu, M.I. (2015). Tool selection for rough and finish CNC milling operations based on toolpath generation and machining optimisation, Advances in Production Engineering \& Management, Vol. 10, No. 1, 18-26, doi: 10.14743/apem2015.1.189.

[4] Milfelner, M., Cus, F., Balic, J. (2005). An overview of data acquisition system for cutting force measuring and optimization in milling, Journal of Materials Processing Technology, Vol. 164-165, 1281-1288, doi: 10.1016/ j.jmatprotec.2005.02.146.

[5] Liu, X.-W., Cheng, K., Webb, D., Luo, X.-C. (2002). Improved dynamic cutting force model in peripheral milling. Part I: Theoretical model and simulation, The International Journal of Advanced Manufacturing Technology, Vol. 20, No. 9, 631-638, doi: 10.1007/s001700200200.

[6] Ikua, B.W., Tanaka, H., Obata, F., Sakamoto, S. (2001). Prediction of cutting forces and machining error in ball end milling of curved surfaces -I theoretical analysis, Precision Engineering, Vol. 25, No. 4, 266-273, doi: $10.1016 /$ S0141-6359(01)00077-0.

[7] Qu, S., Zhao, J., Wang, T., Tian, F. (2015). Improved method to predict cutting force in end milling considering cutting process dynamics, The International Journal of Advanced Manufacturing Technology, Vol. 78, No. 9-12, 1501-1510, doi: 10.1007/s00170-014-6731-5. 
[8] Han, Z., Jin, H., Fu, H. (2015). Cutting force prediction models of metal machining processes: A review, In: Proceedings of 2015 International Conference on Estimation, Detection and Information Fusion (ICEDIF), Harbin, China, 323-328, doi: 10.1109/ICEDIF.2015.7280216.

[9] Gradišek, J., Kalveram, M., Weinert, K. (2004). Mechanistic identification of specific force coefficients for a general end mill, International Journal of Machine Tools and Manufacture, Vol. 44, No. 4, 401-414, doi: 10.1016/ j.ijmachtools.2003.10.001.

[10] Saric, T., Simunovic, G., Simunovic, K. (2013). Use of neural networks in prediction and simulation of steel surface roughness, International Journal of Simulation Modelling, Vol. 12, No. 4, 225-236, doi: 10.2507/IJSIMM12 (4) 2.241.

[11] Martellotti, M.E. (1945). An analysis of the milling process, Part II: Down milling, Transactions of ASME, Vol. 67, No. 4, 233-251.

[12] Gonzalo, O., Beristain, J., Jauregi, H., Sanz, C. (2010). A method for the identification of the specific force coefficients for mechanistic milling simulation, International Journal of Machine Tools and Manufacture, Vol. 50, No. 9, 765-774, doi: 10.1016/j.ijmachtools.2010.05.009.

[13] Budak, E., Altintaş, Y., Armarego, E.J.A. (1996). Prediction of milling force coefficients from orthogonal cutting data, Journal of Manufacturing Science and Engineering, Vol. 118, No. 2, 216-224, doi: 10.1115/1.2831014.

[14] Spiewak, S. (1995). An improved model of the chip thickness in milling, CIRP Annals, Vol. 44, No. 1, 39-42, doi: 10.1016/s0007-8506(07)62271-9.

[15] Li, H.Z., Liu, K., Li, X.P. (2001). A new method for determining the undeformed chip thickness in milling, Journal of Materials Processing Technology, Vol. 113, No. 1-3, 378-384, doi: 10.1016/S0924-0136(01)00586-6.

[16] Kumanchik, L.M., Schmitz, T.L. (2007). Improved analytical chip thickness model for milling, Precision Engineering, Vol. 31, No. 3, 317-324, doi: 10.1016/i.precisioneng.2006.12.001.

[17] Song, G., Li, J., Sun, J. (2013). Approach for modeling accurate undeformed chip thickness in milling operation, The International Journal of Advanced Manufacturing Technology, Vol. 68, No. 5-8, 1429-1439, doi: 10.1007/ s00170-013-4932-y.

[18] Saï, L., Bouzid, W., Zghal, A. (2008). Chip thickness analysis for different tool motions: For adaptive feed rate, Journal of Materials Processing Technology, Vol. 204, No. 1-3, 213-220, doi: 10.1016/i.jmatprotec.2007.11.094.

[19] Grossi, N., Sallese, L., Scippa, A., Campatelli, G. (2015). Speed-varying cutting force coefficient identification in milling, Precision Engineering, Vol. 42, 321-334, doi: 10.1016/i.precisioneng.2015.04.006.

[20] Fu, G. (2000). Basic knowledge of metal cutting, In: Shi, Q.F, Wang, L. (eds.), Metal cutting manual, (Third edition), Shanghai Science and Technology Press, Shanghai, 1-31, (in Chinese).

[21] Altintas, Y. (2012). Manufacturing automation: Metal cutting mechanics, machine tool vibrations, and CNC design, (Second edition), Cambridge University Press, New York, USA, doi: 10.1017/CB09780511843723.

[22] Moufki, A., Dudzinski, D., Le Coz, G. (2015). Prediction of cutting forces from an analytical model of oblique cutting, application to peripheral milling of Ti-6Al-4V alloy, The International Journal of Advanced Manufacturing Technology, Vol. 81, No. 1-4, 615-626, doi: 10.1007/s00170-015-7018-1.

[23] Armarego, E.J.A., Deshpande, N.P. (1993). Force prediction models and CAD/CAM software for helical tooth milling processes. II. Peripheral milling operations, International Journal of Production Research, Vol. 31, No. 10, 2319-2336, doi: $10.1080 / 00207549308956860$. 


\section{APEM}

Advances in Production Engineering \& Management Letnik 13 | Številka 3 | September 2018 | Strani 297-306 https://doi.org/10.14743/apem2018.3.291
ISSN 1854-6250

Spletna stran: apem-journal.org Izvirni znanstveni članek

\title{
Celovit algoritem za merjenje trenutne debeline neodrezanega odrezka pri rezkanju
}

\author{
Li, Y. ${ }^{a}$, Yang, Z.J. ${ }^{a}$, Chen, C. ${ }^{b,}{ }^{*}$, Song, Y.X. ${ }^{a}$, Zhang, J.J. ${ }^{a}$, Du, D.W. ${ }^{c}$ \\ ${ }^{a}$ College of Mechanical Science and Engineering, Jilin University, Changchun, Jilin, P.R. China \\ ${ }^{b}$ College of Engineering, China Agricultural University, Beijing, P.R. China \\ ${ }^{c}$ Institution of Oceangraphic Instrumentation, Shandong Academy of Science, Qingdao, P.R. China
}

\section{POVZETEK}

Natančno izračunavanje trenutne debeline neodrezanega odrezka (IUCT) je bistvenega pomena za natančno napoved dinamične rezalne sile pri rezkanju. Ta študija predstavlja integralni algoritem v polarnem koordinatnem sistemu za merjenje debeline trenutnega neodrezanega odrezka. Za opis poti rezkarja je privzeto ciklično gibanje. V modelu sta upoštevana neprekinjenost rezkanja in iztek orodja. Razviti model ponuja metodologijo za natančno izračunavanje IUCT. Poleg tega je izveden niz simulacij pri različnih obdelovalnih parametrih. Rezultati kažejo, da hkratno povečanje podajanja na zob in števila zob nekoliko poveča širino IUCT, ki pa se zmanjša z manjšim polmerom orodja. Simulacije rezalne sile potrjujejo rezultati preizkusov, ki so bili dobljeni v referenčni literaturi in primerjani s klasično metodo aproksimacije. Rezultati pričujoče raziskave nakazujejo možnost učinkovite uporabe modela IUCT pri napovedi trenutne rezalne sile.

(C) 2018 CPE, University of Maribor. All rights reserved.

\section{PODATKI O ČLANKU}

Ključne besede:

Rezkanje;

Trenutne debelina neodrezanega odrezka;

Dinamične rezalne sile;

Integracijski algoritem

*Kontaktna oseba:

chenchao2018@cau.edu.cn

(Chen, C.)

Zgodovina članka:

Prejet 7. decembra 2017

Popravljen 29. julija 2018

Sprejet 24. avgusta 2018 